\title{
The evolution of concrete shells; innovations by Ildefonso Sánchez del Río
}

\author{
La evolución de las estructuras laminares; \\ innovaciones de Ildefonso Sánchez del Río
}

$\underline{\text { P. Cassinello }}^{(*)}$

\section{SUMMARY}

The legacy of Ildefonso Sánchez del Río Pisón (1898-1980) contains some of the most pioneer Spanish concrete shells. It's a fact that the "Modern Architecture's Thin Shells Adventure" had just start when he designed and built his first work in Spain (1924). In the international context prevailing in the twenties, the reinforced concrete was still evolving. The first Thin Concrete Shells was built by Dyckerhoff and Widman in Jena, Germany (1922-1925). Ildefonso Sánchez was looking for a system to design concrete shells in a simple way. Finally, he founded his own and innovate system based in a similar method to the ribbed Gothic Vault. He used his system to built a very different ribbed concrete shell, such as the Sport Hall of Oviedo, Spain (90 m span). This article contains some results about the research on Sánchez del Río's work and its repercussion on the international context.

108-16

Keywords: Reinforced concrete; shell structures; innovation; patent; technology; prefabrication.

\section{RESUMEN}

El legado de Ildefonso Sánchez del Río Pisón (1898-1980) contiene algunas de las más pioneras estructuras laminares españolas. Es un hecho que la "Aventura Laminar de la Arquitectura Moderna" empezó cuando él proyectó y construyó sus primeros trabajos en España (1924). En el contexto internacional de la década de los años veinte, el hormigón armado estaba todavía en desarrollo. La primera estructura laminar fue construida por Dyckerhoff and Widman en Jena. Alemania (1922-1925). Ildefonso Sánchez buscó un método sencillo de diseño. Finalmente, encontró su propio e innovador sistema, que estaba basado en un método similar al de las bóvedas nervadas del Gótico. Usó este sistema para construir diferentes estructuras laminares, como el Palacio de Deportes de Oviedo, España (90 m luz). Este artículo contiene algunos de los resultados de la investigación que he realizado sobre el trabajo de Sánchez del Río y su repercusión en el contexto internacional.
Palabras clave: Hormigón armado; estructuras laminares; innovación; patentes; tecnología; prefabricación. 


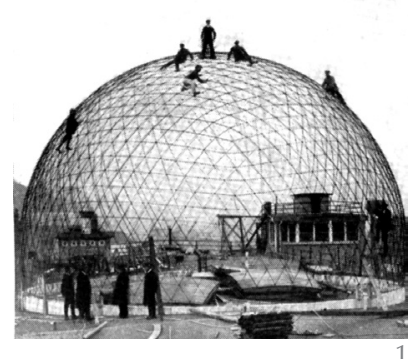

1. Zeiss Planetarium at Jena, Germany 1922. Franz Dischinger.

2. Hangars at Orly, France 1923. Eugene Freyssinet.

\section{INTRODUCTION}

Ildefonso Sánchez del Río Pisón (18981980) was one of the most outstanding Spanish engineers of the so-called Generation of 1927. Along with José Entrecanales, Eduardo Torroja and Carlos Fernández Casado, he trained at Madrid's School of Civil Engineering with Eugenio Ribera, a master and pioneer of the use of reinforced concrete in Spain.

His extensive legacy has earned him a place as one of the guideposts of Spanish engineering. His oeuvre attained international renown thanks to his innovative system of building with corrugated thin shells. This technique, developed from the late nineteen forties onward, was based on precasting lightweight fired clay and reinforced concrete modules, this engineer's famous corrugated voussoirs. He used this system to build what is indisputably his masterpiece, the Oviedo Sports Pavilion (19611975). Featured on the cover of one of the issues of the International Association for Shell Structures bulletin, the pavilion now forms part of the history of the development of thin shells.

\section{INTERNATIONAL CONTEXT: FROM REINFORCED CONCRETE SPATIAL ROOFS TO MODERN ARCHITECTURE'S THIN SHELLS}

The advent of reinforced concrete in the early twentieth century revolutionised civil works and building. Engineers world-wide soon realised that they could capitalise on the strength and formal versatility of this new material and its unquestionable preeminence over iron in terms of fire performance to build bridges and roofs with very long spans. Initially (1900-1920), reinforced concrete spatial roofs imitated the spatial wrought iron frames popular in the nineteenth century, based on lattices or continuous series of arches or deep beams. Construction on what is internationally regarded as the first reinforced concrete thin shell was concluded in Jena, Germany in 1922 (1). From that time on, with the discovery of a technological language specific to this new material, the aim was to further develop the thin shell model. Shortly thereafter, in 1929, the first International Congress of Modern Architecture consolidated the new "air" that was bringing radical change to all disciplines: architecture, engineering, music, painting, sculpture, poetry... In the decades that followed, thin concrete shells also became the ultimate symbol of that new paradigm ("less is more"), constituting the core of a broad legacy of new, effective and essentially bare structural forms.
One of the first roofs to be made of reinforced concrete covered the tiny Bürkliplatz Pavilion built by Robert Maillart in 1908, who invented his mushroom-like slab that same year (2). Just one year later, in 1909, the Swanson Brothers built the roof over the Melbourne Public Library, an octagonal dome measuring 34.8 metres in diameter, at the time the largest such reinforced concrete structure ever built. In 1913 its record was appropriated by the Hala Stulecia (Centennial Hall) at Wroclaw, Poland, whose 65-metre diameter roof was designed by architect Max Berg, engineered by Willi Gehler and Günther Trauer and built by the pioneer German firm Dyckerhoff and Widman. Functionally speaking, the primary characteristic of these large reinforced concrete roofs was that they imitated their predecessors, spatial wrought iron roofs (3).

Shortly after Ildefonso Sánchez del Río Pisón undertook his engineering career in 1922, he was designated municipal engineer of the City of Oviedo. That appointment came in 1922-1924, when the world's first thin shell was under construction at Jena, Germany, authored by Walter Bauersfeld and built by Dyckerhoff and Widman under the orders of that firm's chief engineer, Franz Dischinger (Figure 1). That feat followed on Eugene Freyssinet's design, in 1923, for his famous hangars at Orly: cylindrical barrel vaults with a parabolic crosssection and corrugated surface, 144 metres long and spanning a distance of 75 metres (Figure 2). These events were to change the destiny of reinforced concrete spatial roofs in the decades that followed.

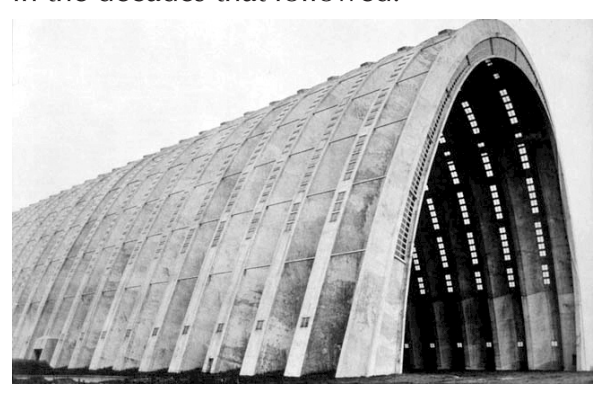

Given the difficulty inherent in engineering these incipient thin shells, in the nineteen twenties, at the outset of his career, Sánchez del Río developed his own method for reinforced concrete roof design. He based their structure on geometric shapes that could be simply built and dimensioned with frames consisting of continuous ribs (beams or arches) set on their narrow side and lightweight severy-like elements in between to minimise the overall weight of the roof. This was the model he used in his famous early "umbrella"-like roofs, as well as in the roofs over water tanks and the singular roof over the Pola de Siero Market (1929), with 
its two intersecting cylindrical barrel vaults, for which he designed a highly original arch that spans 50 metres (Figure 3). The construction of this innovative roof concurred with three legendary structures in the history of thin concrete shells: the Frankfurt Market Hall (1926-1927), designed by Martín Elsässer, Franz Dischinger and Ulrich Finsterwalder; the Leipzig Market (1927-1929), designed by Hubert Ritter, Franz Dischinger and Hubert Rüsch and the Basil Market (1929) an octagonal dome 60 metres in diameter and only $8 \mathrm{~cm}$ thick, designed by Hans E. Ryhiner, Franz Dischinger and Alfred A. Göenn.

That same year, 1929, Eugene Freyssinet patented "prestressed concrete", a new materia that was to contribute to the development of new and larger civil and architectural works, with a direct impact on thin shells.

In the nineteen thirties, many of the lead players in the development of reinforced and prestressed concrete and thin shells built some of their most prominent structures (Kurrer 2008). These included: Eduardo Torroja (4): Algeciras Market (1934), Zarzuela Race Track (1935) (Figure 4) and Recoletos Jai-Alai Court (1936); Pier Luigi Nervi: hangars at Orvieto (1935); Bernard Lafaille: French pavilion at the Zagreb World Fair (1937); Giorgio Baroni: Entrepot Ferrare (1938); Robert Maillart: Cement Pavilion at the Swiss National Exhibition (1939) (Figure 5); Antón Tedesco: water filter plant, Hibbing (1939).

In the nineteen forties Ildefonso Sánchez del Río developed an innovative system for designing and building lightweight roofs, resorting to the use of corrugated surfaces to attain greater stiffness, much as Freyssinet had done with his hangars at Orly (1923). That system was based on using modules (corrugated voussoirs) precast on site with reinforced concrete and lightweight fired clay elements designed and produced at his Río Cerámica factory. He built many roofs with this system, which by the early nineteen fifties had spans of up to 35 metres. This construction system was similar to the precast corrugated voussoir scheme devised by Pier Luigi Nervi (5) and used in many of his works. In one, the main hall in the Turin Exhibition (1948-1949), the roof spanned a total of 95 metres. Subsequently, also using cylindrical barrels with a corrugated surface, August Perret and Nicolas Esquillan built the Marignane hangars (1950-1952), setting a new record in the span covered by these thin shell barrel vaults with corrugated surfaces: 101.50 metres, using reinforced concrete only $6 \mathrm{~cm}$ thick (Figure 6).

A few years later, in 1958, what was to be the largest thin shell of modernist architecture was built in Paris: a double corrugated ribbed vault spanning 218 metres over a triangular floor plan. The structure, which roofs the Centre des nouvelles industries et technologies (CNIT - centre for new industries and technologies), was authored by Nicolas Esquillan under the guidance of Pier Luigi Nervi (Figure 7) (6).

In 1959, in light of the dynamic development of thin concrete shells, the International Association for Shell Structures, IASS, was founded in Madrid under the leadership of Eduardo Torroja. Sánchez del Río was invited to deliver a lecture on his innovative system for building corrugated shells as part of the International Colloquium on Thin Shell Construction Methods held at the Institute for Construction and Cement (itcc).

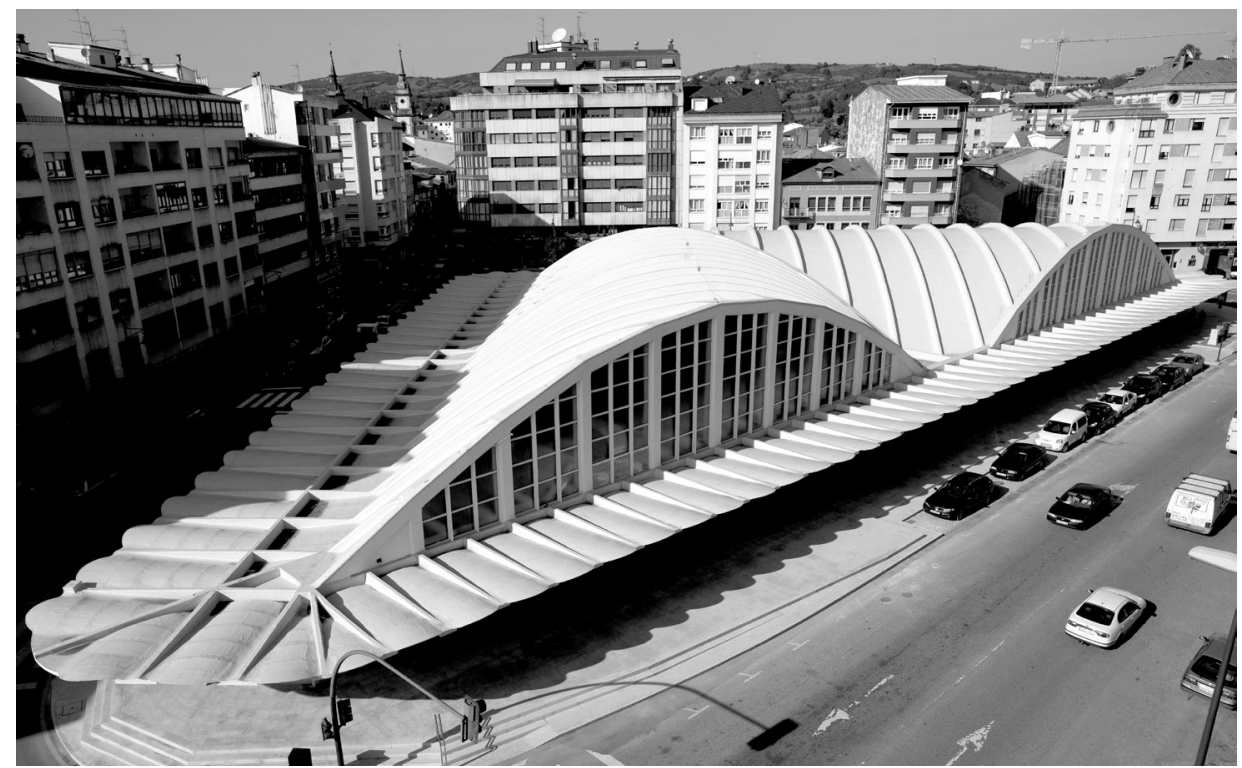

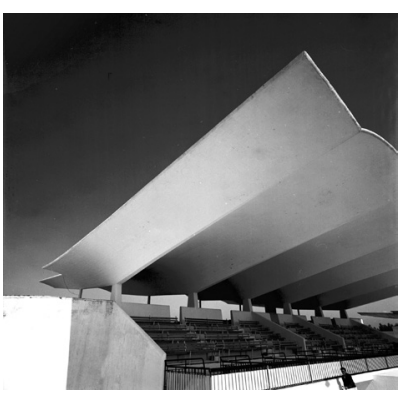
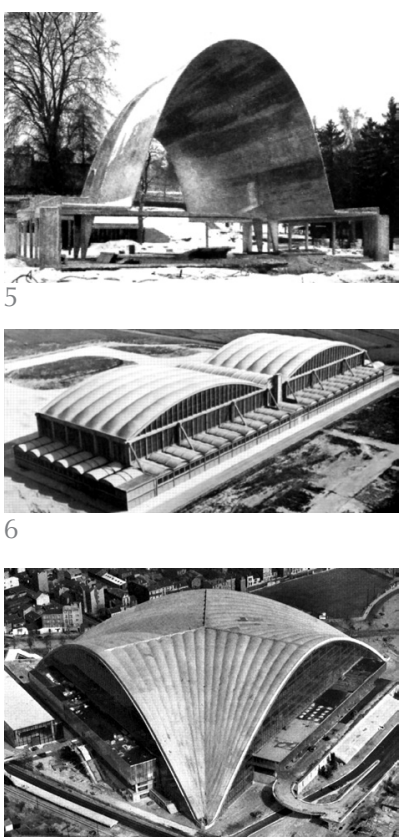

3. Pola de Siero Market, Spain (1929). Ildefonso Sánchez del Río Pisón.

4. Zarzuela Race Track at Madrid, Spain (1935). Eduardo Torroja.

5. Cement Pavilion at the Swiss National Exhibition (1939) Robert Maillart.

6. Marignane hangars, France (1950-1952). August Perret and Nicolas Esquillan.

7. CNIT, Paris, France 1958 Nicolas Esquillan and Pier Luigi Nervi. 
8. Oviedo's fourth water tank, Spain (1926-1928). Ildefonso Sánchez del Río Pisón.

9. Pola de Siero's water tank, Spain (1931). Ildefonso Sánchez del Río Pisón.
The Asturian engineer presented the corrugated shell system that he had developed with different types of corrugated arches and voussoirs and that could theoretically be used to build roofs covering spans of up to 200 metres. Later, in 1961, he began to design what was to be his grand oeuvre, the Oviedo Sports Pavilion, where he also applied the system: the roof, which spans a distance of 100 metres, was completed in 1975. In that same decade, in 1972, he built a roof for the Pola de Siero market consisting of a series of reinforced concrete shell umbrellas, one of which, with a diameter of 40 metres, is the largest thin shell umbrella ever built.

Engineer Ildefonso Sánchez del Río's contributions to the development of reinforced concrete roofs during his career, which lasted over half a century (1924-1975), form part of one of the most significant and admirable histories of the twentieth century: the progression from reinforced concrete spatial roofs to modernist thin shells.

\section{WATER TANKS}

One of the innovations in Sánchez del Río's oeuvre was indisputably his prototype for water tanks. He built several, primarily while he was municipal engineer for the City of Oviedo (1924-1941). It was in Oviedo's fourth water tank (1926-1928) (Figure 8), with a capacity of $10000 \mathrm{~m} 3$, that Sánchez del Río (7), applying the same design method as in his early "umbrellas", defined an innovative type of structural skeleton for reinforced concrete spatial roofs. This solution was substantially more cost-effective than the alternatives available at the time because of its rationalised construction. The method consisted of suitably choosing the geometry for the spatial roof, whose skeleton comprised self-bearing ribs and small elements either resting on or hanging from them. These elements were reinforced concrete shells or slabs or slabs lightened with fired clay components. As Sánchez del Río himself pointed out years

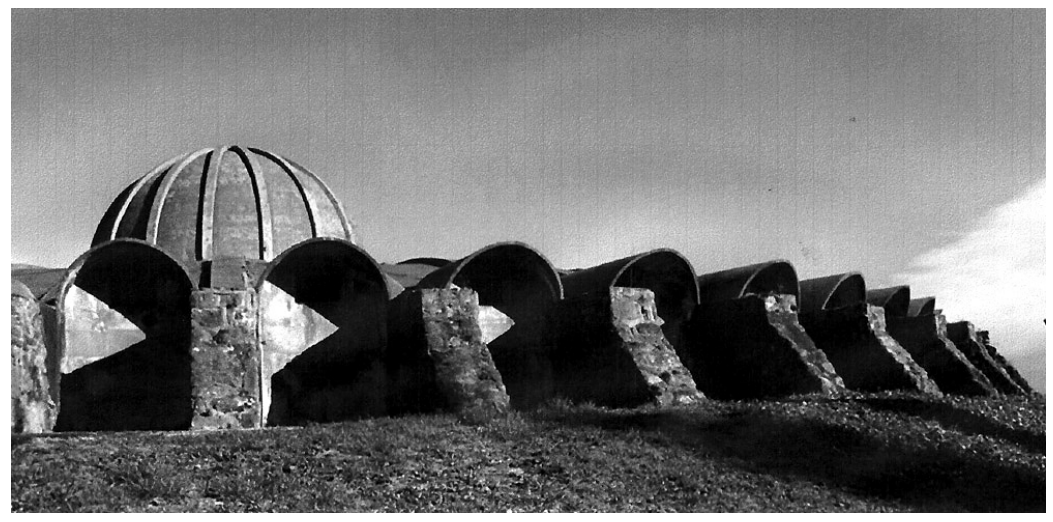

later, this obviated the need to design continuous shells, which would have rendered the structural engineering for the roof of the tank very complex. In these early years, this type of roofs was very scantly developed, as noted in the description of the international context prevailing in the nineteen twenties.

Most of the water tank roofs designed by Sánchez del Río were based on the same type of structural skeleton as the fourth water tank in Oviedo, which was highly praised by his mentor Eugenio Ribera (Sánchez del Río 1928). They were toroidal spatial geometries generally intended for circular floor plans, such as in the water tanks at Trubia (1930), Turón (1930), Pola de Siero (1931) (Figure 9) and Lugones (1943), although some were built over semi-circular plans, such as the storage tank at Mieres (1930).

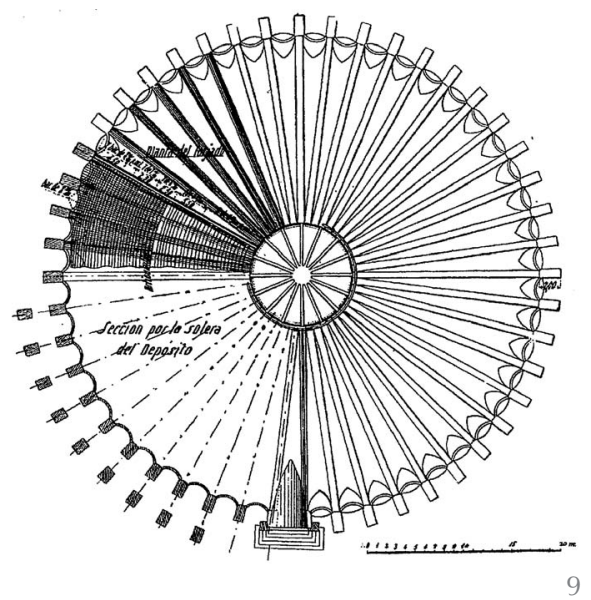

Sánchez del Río perfected his structural system for a standard roof from the experience accumulated in the design of these subsequent storage tanks. He also engineered two large tanks that were never built, one for Madrid and the other for Seville. The exhibit devotes two large panels to this type of structures, and displays original documents from the Fundación Juanelo Turriano archives in connection with the designs for the fourth water tank at Oviedo, dating from 1928, the Pola de Siero water tank, from 1931 and the Madrid tank, from 1932. A scale model of the fourth tank at Oviedo is also shown, courtesy of the Centre for Public Works Studies and Experimentation.

Oviedo's fourth water tank was actually a prototype that Sánchez del Río later perfected (8). This storage tank was built over a circular floor plan 50 metres in diameter. It is toroidal, with a 10-metre diameter cylinder in the centre, like a lantern, roofed by a tiny spherical ribbed dome that houses the machine room. This design shortens the span for the main roof, converting it into a circular barrel vault whose skeleton is a 
continuous series of arched ribs that spring from the machine room dome and rest at the other end on buttresses external to the building.

This ingenious, 20-metre span roof was essentially dimensioned by balancing the actions involved and built, as in Medieval times, by sequentially erecting two opposite sectors to guarantee overall stability during construction with no need for shoring. To that end, Sánchez del Río designed centring that revolved around the machine room, a system that he later applied in other storage tanks, such as at Pola de Siero. Two mobile centring forms positioned diametrically opposite one another were used during the construction of these tanks. Since the two forms together covered an area equal to one twelfth of the total roof, construction was divided into twelve stages.

In 1930, Ildefonso Sánchez del Río designed Madrid's fourth water tank with this same structural system and submitted it to the competition organised by the Canal de Isabel II (municipal waterworks), although he was not awarded the commission. The "8-shaped" storage tank is the result of the spatial coupling of two circular storage tanks with an interior diameter of 150 metres. Further to the structural and construction scheme devised by Sánchez del Río, the two tanks are joined by a common vertical plane that cuts through both. Of the 20 radial ribs that form the skeleton for each of the two storage tanks and converge on this plane, six spring from the common machine room located in between the two adjacent tanks.

If this storage tank had been built, it would have been the largest toroidal structure designed by Sánchez del Río using this construction system.

\section{UMBRELLAS}

Reinforced concrete umbrellas constitute one of the roofing systems characteristic of Ildelfonso Sánchez del Río's pioneering oeuvre, and over the years have become landmarks in the urban fabric of Asturian cities and towns such as Oviedo, Pola de Siero, Olloniego, Corredoria, Lugones and Ciaño (9).

In the nineteen twenties, as municipal engineer, Sánchez del Río proposed this type of structure for the City of Oviedo as an innovative and inexpensive design for roofing outdoor laundry stations, in light of the area's particularly rainy climate. He was the first to use this type of roof which, despite the geometric and structural differences, is clearly a precursor for the continu- ous thin concrete shell umbrellas designed and built in Italy by Giorgio Baroni in the nineteen thirties and Félix Candela in Mexico in the nineteen fifties. Sánchez del Río, in fact, designed these members not as a continuous whole, but applying the same structural design that he used in the rest of his oeuvre, which consisted of building a series of reinforced concrete ribs and covering the gaps between them with (in this case) lightweight fibrecement plates $1 \mathrm{~cm}$ thick that rested on the ribs. Each umbrella has a reinforced concrete column, generally in the centre, with radial ribs springing from its capital like the rods in an ordinary umbrella and inter-braced with concentric hoops. The cross-sections of the linear reinforced concrete members comprising this skeleton are optimised not only thanks to the specific arrangement of ribs and hoops, but also to the fact that they are covered by thin, very lightweight elements that can be likened to the fabric in umbrellas.

The geometries used by Ildefonso Sánchez del Río in his umbrellas are normally very shallow cones or pyramids that can be readily decomposed into radial rib sequences. These geometries were skilfully chosen, not only because they fulfilled their specific architectural purpose, but also because they could be erected with the kind of structural skeleton that their author could readily engineer and build. Most of these structures date from a time when reinforced concrete was in the early stages of development and before what is internationally regarded as the first thin concrete shell was built at Jena, Germany (1922-1925).

Sánchez del Río designed and built a wide variety of reinforced concrete umbrellas, generated by interlacing their members: column, ribs and severy-like fillers. He sometimes positioned the column eccentrically, such as at Ciaño, or inverted the umbrella geometry, such as in the large-scale central umbrella over the Pola de Siero livestock market, which is concave rather than convex. These variations were later adopted by Félix Candela, albeit with very different geometric shapes, to design his admirable and prolific thin shell legacy (10).

The umbrellas were usually designed as stand-alone roofs over small laundry stations strategically placed alongside water fountains for the convenience of the townsfolk, such as at Olloniego and Corredoria (Figure 10). The structure over Fuente de Plata at Oviedo has since disappeared (the fountain it once roofed being all that remains). Nonetheless, Sánchez del Río also applied this structure for other uses, such as his famous "milk" umbrella in Oviedo,

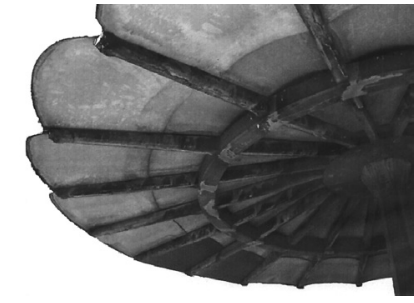

10

10. Umbrella at Corredoria, Oviedo, Spain. Ildefonso Sánchez del Río Pisón. 
11. Umbrella at Pola de Siero, Spain. Ildefonso Sánchez del Río Pisón. whose purpose was to provide cover from the rain for the dairy market in a square now informally known as "Umbrella Square", or for the bandstand at Ciaño. The largest umbrella he ever built roofs the livestock market at Pola de Siero (1971-1972), whose three square outer umbrellas measuring 20 metres on each side surround a central octagonal umbrella 40 metres in diameter. These dimensions were a reference to the $1250-\mathrm{m} 2$ area that could be ploughed by a pair of oxen in one day, although the measure was no longer in use even then.

Sánchez del Río gradually designed larger and larger reinforced concrete umbrellas: the earliest structures, dating from the nineteen twenties, measured just 8 metres across, whereas the Pola de Siero livestock market, built in the nineteen seventies, has a diameter that spans 40 metres, a dimension never exceeded by a reinforced concrete umbrella anywhere in the world. (Figures $11 \mathrm{a}$ and $11 \mathrm{~b}$ ).

\section{PATENTS FOR FIRED CLAY: STRUCTURAL FLOORS AND ROOFS}

Ildefonso Sánchez del Río Pisón was granted a number of patents for fired clay materials that contributed to the development of structural floors in early twentieth century Spain, and to the creation of new and innovative alternatives for the construction of vaulted roofs.

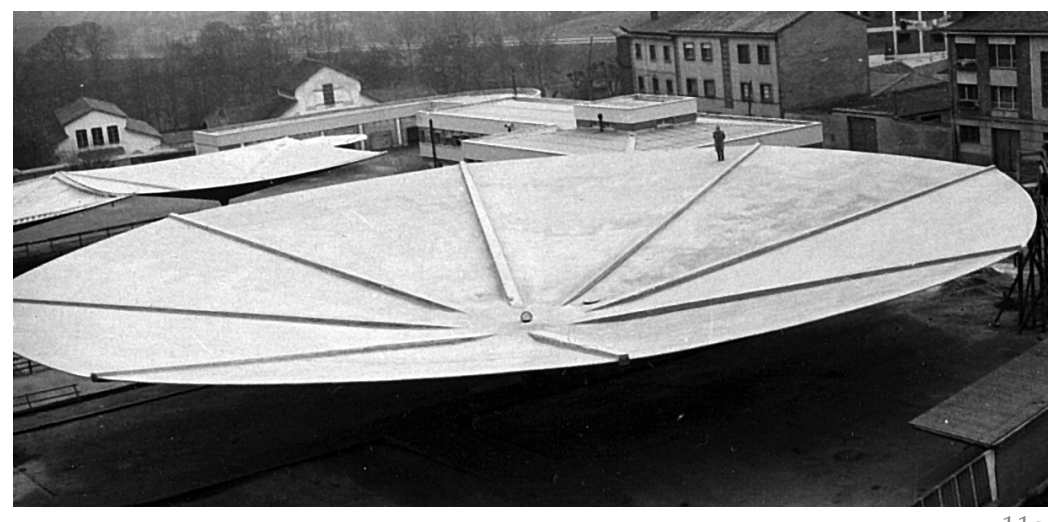

In 1942 he founded his own factory, Río Cerámica S.A., where he produced the products he had patented. The ability to control the entire process from the drawing board to worksite assembly enabled him to gradually introduce improvements in these products.

Drawing from both the new possibilities afforded by the incipient use of reinforced concrete and Spain's long tradition and expertise in manufacturing fired clay, Sánchez del Río registered a total of 15 patents for structural floors between 1935 and 1967. These innovations contributed to the growing use of new types of floors that not only fulfilled their bearing function, but rationalised the construction of what had until then been hand-crafted structural members. These patents introduced a wide variety of joists and pan forms for building one-way structural floors. The respective construction systems ranged from flat floors made of reinforced concrete joists and concrete pan forms to floors in which the fired clay elements housed the bending and shear reinforcement which, once cast in concrete, ensured that the member as a whole would attain the necessary bearing capacity. He designed countless types not only of pan forms and joists, but of ancillary components such as uprights that contributed to overall process rationalisation. These elements for structural floors were used all across the country and the entire suite of patents was declared to be of interest by the Directorate General of Architecture.

\section{CORRUGATED ROOFS}

The patents for fired clay elements in vaulted roofs followed a very different route, for they were used primarily in Sánchez del Río's own works. Thanks to these elements, his legacy contains a long list of widely varying innovative roofs. Like his umbrellas, his roofs also gradually grew in size, from spans of only a few metres in the early years to 100 metres in the Oviedo Sports Pavilion (1961-1975). The small lightweight

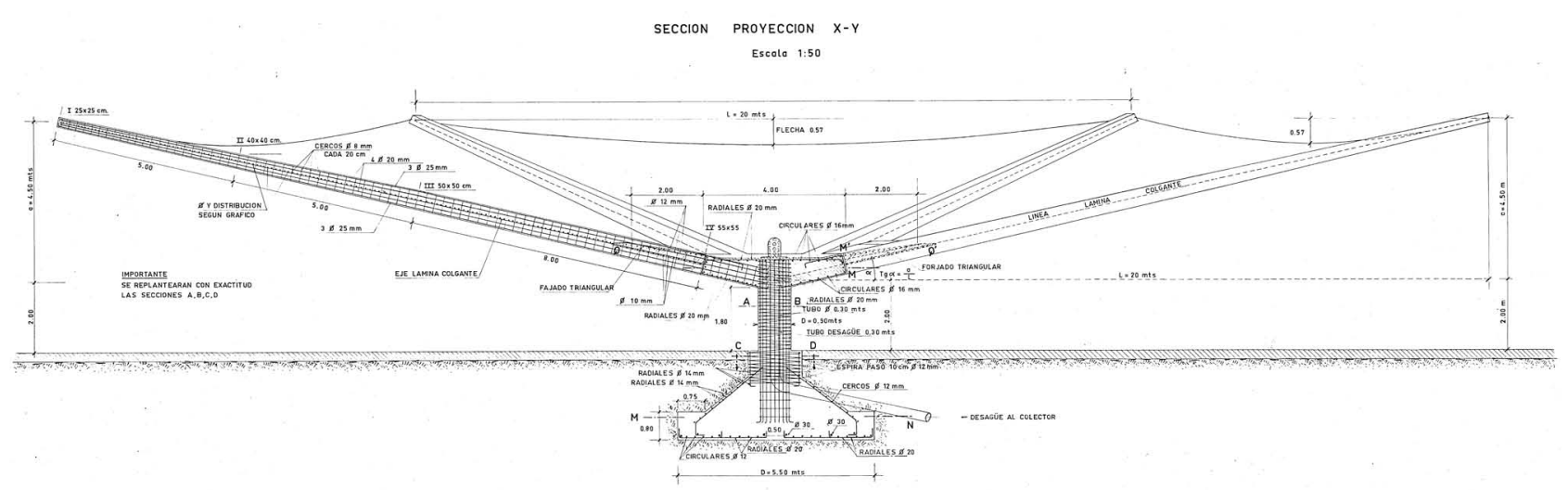


fired clay pan forms patented also evolved, with variations in their geometry, depth and lightening process used, depending on the type and size of the vaulted roof where they were to be laid. The most prominent elements were what Sánchez del Río called corrugated voussoirs, used to build his large-span corrugated roofs. In the nineteen fifties, inspired by thin concrete shell maestros such as Freyssinet and Nervi, who had already built corrugated shell roofs, he developed a similar construction system of his own using corrugation to ensure the formal stiffness needed in such members.

The result, his corrugated voussoirs, were made of lightweight fired clay elements consisting of a vaulted centre and two small straight sections positioned at the edges for readier placement and to house the reinforced concrete ribs cast in between the voussoirs. He used these elements to build the so-called corrugated arches that defined these roofs. The voussoirs were made on site and then hoisted into position. The construction system devised on the basis of these elements earned him acknowledgement for his contribution to the development of modern architecture's thin concrete shells (11).

\section{SPORTS PAVILION}

The Oviedo Sports Pavilion is Ildefonso Sánchez del Río's indisputable masterpiece (Figure 12). It is not only the largest roof that he built, with a span of 100 metres, but also the culmination of his oeuvre, in which he masterfully combined his innovative corrugated roof construction system with the formal composition of the architectural space enclosed (12).

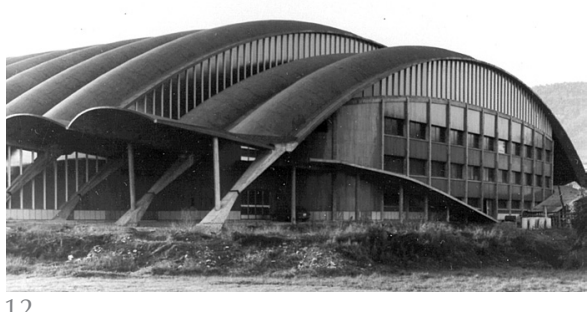

Moreover, by erecting this roof, Sánchez del Río was able to prove that his original design and construction system could effectively be used for large spans thanks to the extraordinary stiffness afforded by corrugation, a solution applied by renowned maestros of the thin shell venture such as Freyssinet in his hangars at Orly (1923), Nervi in much of his oeuvre, including the main exhibition hall at Turin (1948-1949) and Esquillan in his hangars at Marignane (1950-1952), as well as the CNIT in Paris (1958) mentioned above. Sánchez del Río achieved the same effect with his singular and innovative composite (fired clay-concrete) corrugated roofs.

The Oviedo Sports Pavilion roof is a continuous cylindrical barrel vault consisting of three paraboloid, corrugated and double-jointed shells. The central shell consists of eight 7-metre wide corrugated arches spanning 100 metres in all and covering the court, tracks and seating. Two 7-metre wide corrugated arches, one on each side, spanning 90 metres each, articulated at the springing and continuous at the crown, form the side shells. The roof covers a clear floor area measuring $100 \times 100$ metres, bathed in the natural light that beams through the vertical skylights resulting from the difference in height between the central and side shells. This arrangement ensures that the indoor space is perceived by the viewer in all its lightness and grandeur.
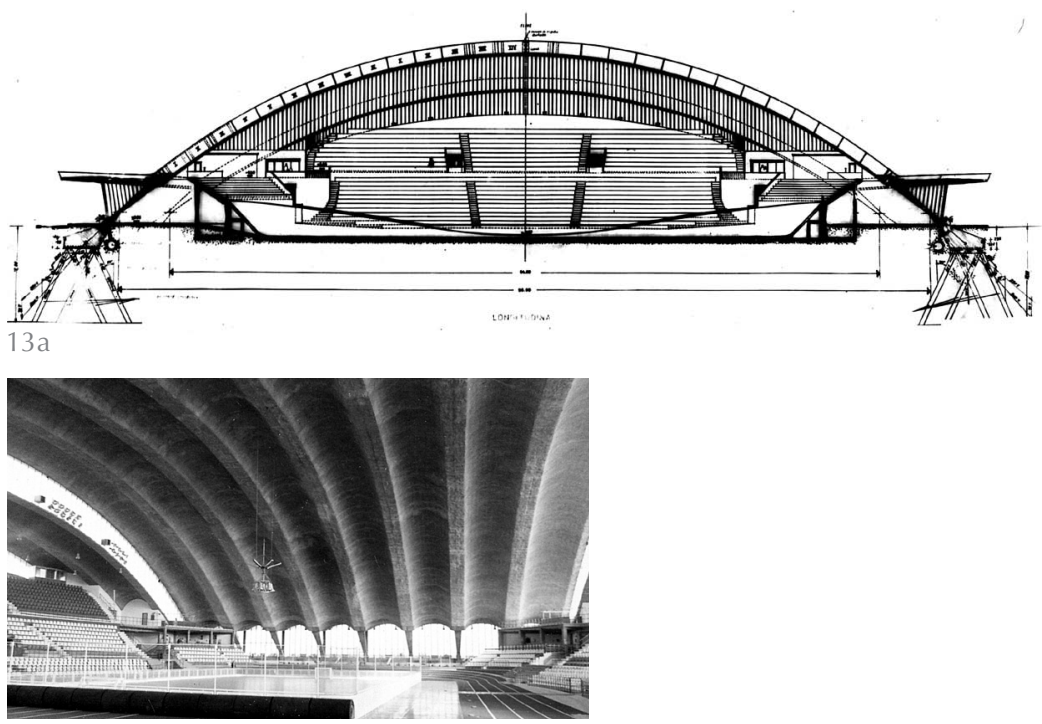

$13 b$

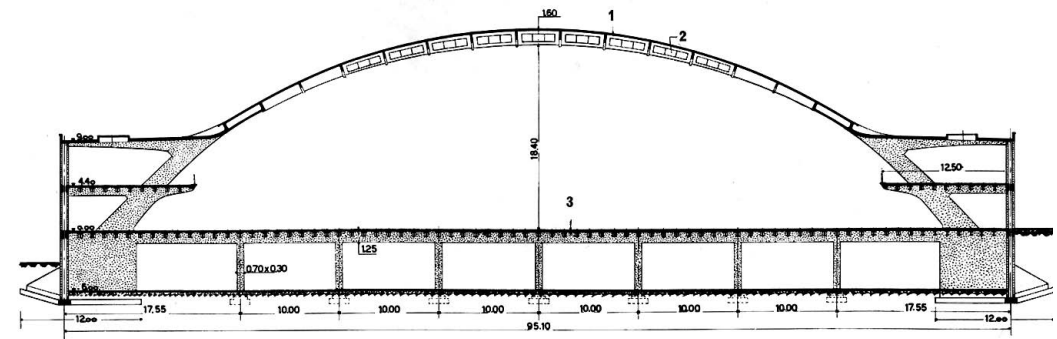

$14 \mathrm{a}$

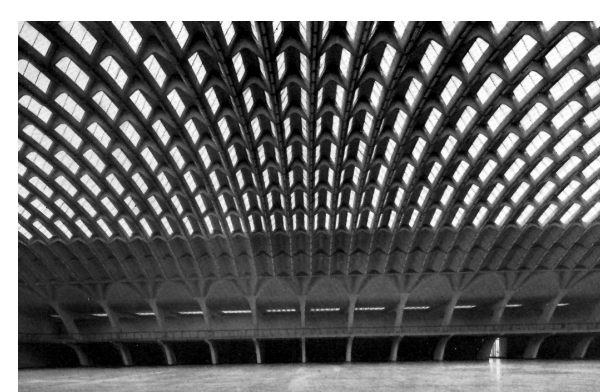

$14 \mathrm{~b}$
12, 13. Oviedo's Sports Pavilion, Spain. Ildefonso Sánchez del Río.

14. Exhibition hall, Turín, Italy. Pier Luigi Nervi. 
The construction system used by Sánchez del Río was very similar to the method applied by Pier Luigi Nervi from the nineteen forties onward. The corrugated modules were manufactured on site and subsequently hoisted into place on formwork to construct the continuous sequence of corrugated arches (Figures 13a, 13b, 14a and 14b). These modules housed the continuing steel for the reinforced concrete ribs that were cast after the formwork was in place to ensure the continuity of the corrugated arches formed. A thin surface layer of reinforced concrete, only a few centimetres thick, was also poured over the extrados of the shell surface. This afforded the shell the continuity needed to guarantee its strength and stability, even though its corrugated arches comprised modular fragments. The essential differences between the Sánchez del Río and Nervi systems lay in the geometry of the corrugated

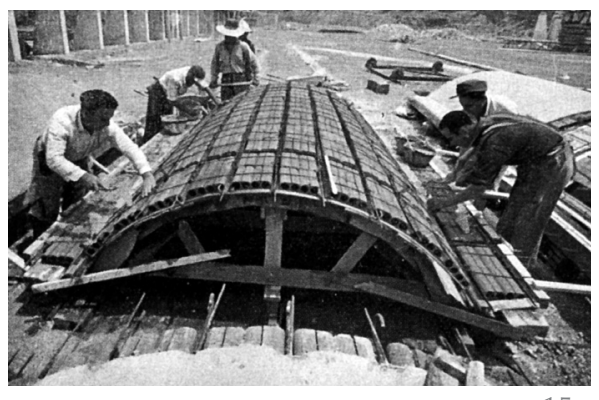

modules and the fact that Nervi's elements were made of reinforced concrete, whereas Sánchez del Río's were made of lightweight fired clay with reinforced concrete ribs (Figures $15 \mathrm{a}$ and $15 \mathrm{~b}$ ).

That innovation was acknowledged by the International Association for Shell Structures (IASS), founded under the leadership of Eduardo Torroja in 1959. A photo of the Oviedo Sports Pavilion, although still under construction at the time, was chosen for the cover of the March 1969 IASS Bulletin.

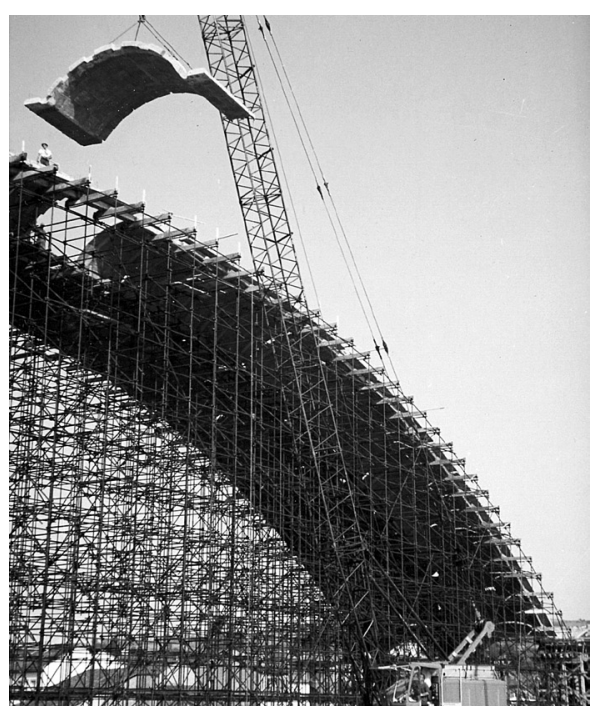

\section{REFERENCES}

(1) Kurrer, K. (2008). The History of the Theory of Structures. Berlin: Ernst and Sohn Verlag für Architecktur und Technische.

(2) Billington, D. (1991). Robert Maillart and the Art of Reinforced Concret. Architectural History Foundation.

(3) Abram, J. (1999). L'architecture moderne. France de 1889. Paris: Editions Picard.

(4) Torroja, E. (1957). Razón y ser de los tipos estructurales. Madrid: Instituto de la Construcción y del Cemento.

(5) Nervi, P.L. (1957). Pier Luigi Nervi. Bauten und Projekte. Stuttgart: Verlag Gerd Hatje.

(6) Joedicke, J. (1962). Les Structures en Volles et Coques. Paris: Vicent Fréal et cie éditeurs.

(7) Sánchez del Río, I. (1928). Cuarto Depósito de Aguas de Madrid. Journal Obras Públicas del Colegio de Ingenieros Madrid, 78, Tomo 1: 269-272.

(8) Sánchez del Río, I. (1930). Cuarto Depósito de Aguas de Madrid y algunas consideraciones más. Journal Obras Públicas del Colegio de Ingenieros Madrid, 78, Tomo 1: 99-102.

(9) Sánchez del Río, I. (1931).Paraguas de hormigón armado en Oviedo, o el ojo clínico del ingeniero. Journal Obras Públicas del Colegio de Ingenieros Madrid, 79, Tomo 1: 302-305

(10) Cassinello, P. (2010). Félix Candela. Centenario / Centenary. Madrid: Universidad Politécnica de Madrid and Fundación Juanelo Turriano.

(11) Sánchez del Río, I. (1960). Estructuras Laminares Cerámicas. Informes de la Construcción, n. ${ }^{\circ} 109$.

(12) Sánchez del Río, I. (1977). Palacio de los Deportes de Oviedo. Informes de la Construcción, 29(287): 73. 